\title{
Marine open cage aquaculture in the eastern Mediterranean Sea: a new trophic resource for bottlenose dolphins
}

\author{
Chiara Piroddi $^{1,2, *}$, Giovanni Bearzi ${ }^{2}$, Villy Christensen ${ }^{1}$ \\ ${ }^{1}$ Fisheries Centre, University of British Columbia, 2202 Main Mall, Vancouver, British Columbia V6T1Z4, Canada \\ ${ }^{2}$ Tethys Research Institute, Viale G.B. Gadio 2, 20121 Milano, Italy
}

\begin{abstract}
Over the last 2 decades marine open cage aquaculture in the Mediterranean Sea has grown rapidly, leading to increased productivity in the water column near fish farms. Here we investigated the effect of such increase in productivity on the common bottlenose dolphin Tursiops truncatus. We developed an ecosystem model for the inner Ionian Sea Archipelago, western Greece, to: (1) evaluate the trophic interactions between bottlenose dolphins and their surrounding ecosystem, including cage-associated organisms; (2) investigate simultaneously 3 hypotheses that could explain bottlenose dolphin dynamics: (a) increasing fishing effort and changes in ocean productivity, (b) competition with other species, and (c) increase in number of fish farms; and (3) explore spatial trends in bottlenose dolphins distribution using the increased number of fish farms as an explanatory variable. Comparisons of model predictions with historical time-series data indicate that only the increase in number of cages and thereby in productivity near fish farms contributed to the trends observed in dolphin numbers. Spatial analysis also confirmed an increase in occurrence of these dolphins in the proximity of the farms. These outcomes suggest that high productivity in waters surrounding fish cages-within a coastal area that is markedly oligotrophic - may attract bottlenose dolphins. The present study shows that open cage aquaculture has benefited bottlenose dolphins by easing their way of catching prey. Further studies should be conducted in other areas of the Mediterranean Sea to investigate whether the higher occurrence of bottlenose dolphins around fish cages is a common pattern and if it is driven by the trophic status of the ecosystem or by the type of fishes that surround the cages.
\end{abstract}

KEY WORDS: Bottlenose dolphin · Fish farms · Ionian Sea · Ecosystem modelling approach Resale or republication not permitted without written consent of the publisher

\section{INTRODUCTION}

The Mediterranean Sea is among the 5 most diverse ocean areas in terms of species richness (it hosts $>17000$ species), and it contributes to the world's marine biodiversity with an estimate of $7 \%$ (Coll et al. 2010, Costello et al. 2010). Yet, it is one of the most threatened seas on earth (Costello et al. 2010)_habitat loss, overfishing, pollution, and climate change being major stressors affecting marine biodiversity (Coll et al. 2010, 2011). Marine open cage aquaculture, which has increased exponentially since the early 1990s, has added to such impacts through introduction of chemicals, pathogens, and of genetically modified fish (Katranidis et al. 2003, UNEP/MAP/MED POL 2004). Considerable effort has been devoted to the investigation of the various impacts of open cage aquaculture on coastal ecosystems. Studies that explored the effects of feed waste on benthic communities and bottom strata suggest that impacts occur mainly in the vicinity of the farms in relation to the physical, hydrographic, and ecological characteristics of the site (Sar et al. 2004, Machias et al. 2005). The release of nutrients caused 
by feed waste is considered a critical aspect of fish farms development (Pitta et al. 1998a, Karakassis et al. 2005). Observed increases in wild-fish biomass surrounding fish farms have been attributed to pellets lost through cages and/or particulate organic matter from broken pellets and faeces (Dempster et al. 2002, Machias et al. 2004, Giannoulaki et al. 2005, Machias et al. 2005). Few studies have looked at the effects of open cage aquaculture on higher levels of the food web, including top predators such as dolphins (although see Díaz López et al. 2005, WatsonCapps \& Mann 2005). The importance of these effects in terms of habitat loss, potential for incidental mortality, and benefits deriving from increased prey availability or ease to catch such prey is currently being debated (Würsig \& Gailey 2002, Bearzi et al. 2009). In several areas of the Mediterranean Sea, scientists have observed an increased occurrence of common bottlenose dolphins Tursiops truncatus (hereafter 'bottlenose dolphin') near fish farms (Díaz López \& Bernal Shirai 2007, Bearzi et al. 2009), where these dolphins engage in opportunistic foragingpossibly following a decline in their prey throughout the basin (Stergiou \& Koulouris 2000, Coll et al. 2008, 2009, Piroddi et al. 2010).

In the inner Ionian Sea Archipelago, the focus of our study, surveys at sea conducted between 1997 and 2008 have evidenced a relatively stable biomass trend in bottlenose dolphins (Bearzi et al. 2008a) despite rapid declines in the abundance of other marine megafauna (Bearzi et al. 2008a). For example, short-beaked common dolphin Delphins delphis and monk seal Monachus monachus have rapidly declined, partially due to local overfishing (Androukaki et al. 1999, Bearzi et al. 2008a), but no decline for sympatric bottlenose dolphins has been recorded (Piroddi et al. 2010). Plausible hypotheses behind the bottlenose dolphin dynamics could be related to: (1) its adaptability to changes in prey availability, despite declines in the main prey sources caused by fishing and/or environmental changes; (2) the competition release induced by the decline of other top predators feeding in the same areas; and (3) its adaptability to find alternative food supply (e.g. around cage aquaculture facilities).

Ecosystem-based approaches explore the dynamic linkages between marine organisms and human pressure (Mace 2001, Pauly \& Christensen 2002, Pauly et al. 2002, Smith et al. 2007, Crowder et al. 2008, Heithaus et al. 2008). In particular, ecosystem models such as the freely available software Ecopath with Ecosim (www.ecopath.org) have been suggested to be the most suitable tools for assessing the direct and indirect effects of anthropogenic pressures on marine mammals and for evaluating the possible ecological consequences of their dynamics (Plagányi \& Butterworth 2004, Morissette et al. 2010).

We used an ecosystem-based approach to: (1) investigate the trophic interactions between bottlenose dolphins and their surrounding ecosystem, including cage-associated organisms; (2) evaluate 3 factors simultaneously that could explain bottlenose dolphin dynamics: (a) increased fishing effort and changes in ocean productivity, (b) competition with other species, and (c) increased number of fish farms; and (3) explore spatial trends in bottlenose dolphin distributions.

\section{MATERIALS AND METHODS}

\section{Study area}

The present study was conducted in the inner Ionian Sea Archipelago, western Greece (Fig. 1). The area, covering $\sim 1020 \mathrm{~km}^{2}$ of sea surface, is extremely oligotrophic (Casotti et al. 2003), with values of chlorophyll $a$, nutrients, and particulate organic carbon among the lowest found in Mediterranean coastal waters (Pitta et al. 1998b). Here, floating fish farm cages have expanded rapidly along the coastal shelves since the late 1980s. These cages were initially used to rear European seabass Dicentrarchus labrax and gilthead seabream Sparus aurata. More recently, operations have expanded to include fish such as white seabream Diplodus sargus sargus, brown meagre Sciaena umbra, and common pandora Pagellus erythrinus (Conides \& Kevrekidis 2005).

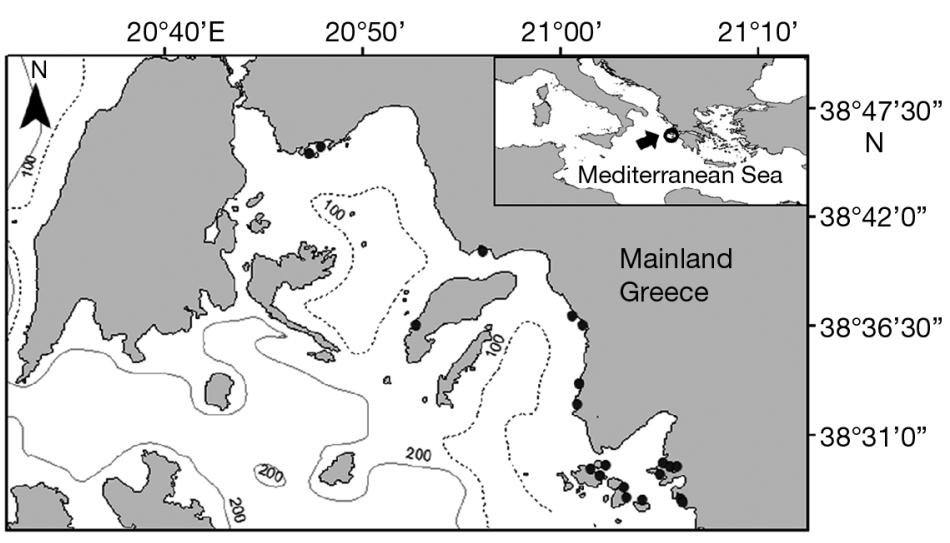

Fig. 1. Study area with bathymetric contour lines (in $\mathrm{m}$ ) and fish farm locations (black dots) 


\section{The model}

Ecopath is a mass-balanced model that provides a static description of an ecosystem at a precise period in time (Christensen \& Walters 2004, Christensen et al. 2008). It can describe principal species of autotrophs and heterotrophs individually or by aggregating them into functional groups (species with a similar ecotrophic role), while incorporating data on biomass $\left(\mathrm{t} \mathrm{km}^{-2}\right)$, total food consumption rate $(Q / B)$, total biological production rate $(P / B)$, and diet composition (expressed as a fraction of prey in the average diet of a predator). Fishing activities can also be included by adding data on landings $\left(\mathrm{t} \mathrm{km}^{-2}\right.$ ), discards $\left(\mathrm{t} \mathrm{km}^{-2}\right)$, and bycatch $\left(\mathrm{t} \mathrm{km}^{-2}\right)$, as well as bioeconomic parameters (i.e. value and cost; Christensen et al. 2008).

\section{Data}

Our food-web model, built using Ecopath with Ecosim v. 6 and based on the previous work of Piroddi et al. (2010), consisted of 19 functional groups representing marine mammals, turtles, sea birds, fishes, invertebrates, and primary producer groups. It represented the study ecosystem in 1964 and included data on biomass, production, consumption, diet, and catch. A full model description can be found in Piroddi et al. (2010). To this model we added another 3 functional groups representing planktivores, zooplankton, and phytoplankton, which are present near fish farm cages, to account for increased productivity around fish farms. For these functional groups, we assumed low levels of biomass at the beginning of the study (1964), because at that time there were no fish farms in the area. Production over biomass $(P / B)$ and consumption over biomass $(Q / B)$ for cage-associated planktivores were estimated by averaging the $P / B$ and $Q / B$ values as calculated for the other pelagic and demersal functional groups. For cage-associated zooplankton and cage-associated phytoplankton, the $P / B$ and $Q / B$ were the same as for the previous zooplankton and phytoplankton group. The diet composition for cage-associated planktivores was assumed to be composed of zooplankton and phytoplankton originating in the vicinity of the farm cages. The cage-associated planktivore group was also added to the bottlenose dolphin Tursiops truncatus diet as a small percentage (1\%) due to the absence of fish farms at the beginning of the study. Cage-associated zooplankton was assumed to feed exclusively on cage-associated zoo- plankton and cage-associated phytoplankton. The modified Ecopath basic input parameters and diet matrix are shown in Tables $1 \& 2$.

\section{Dynamic simulations}

ECosim is a time-dynamic component of EwE (ECOpath with Ecosim) and uses a series of differential equations to calculate temporal changes in biomass of selected functional groups (Walters et al. 1997, Christensen \& Walters 2004). Ecosim runs dynamic simulations of the Ecopath model, incorporating time series estimates of biomass, catch per unit effort (CPUE), and catches for those functional groups with available information. This model is based on the 'foraging arena theory' (Walters et al. 1997), which describes interactions between predators and prey by attributing a vulnerability term to each of these interactions. In particular, low values of vulnerability (close to 1) mean that prey production determines the predation mortality (a phenomenon known as 'bottom-up' control), while high values of vulnerability (close to 100) mean that predator biomass determines how much prey is consumed ('top-down control'; Christensen \& Walters 2004).

The Ecosim simulations run by Piroddi et al. (2010) to explore the temporal dynamics of the main marine organisms of the inner Ionian Sea Archipelago were not able to reproduce the abundance trend of bottlenose dolphins. The model suggested that trophic interactions, increased fishing effort, and changes in nutrient concentration were not the main factors affecting bottlenose dolphin trajectory. For this reason, we decided to investigate in more detail the observed trend of bottlenose dolphin biomass from 1997 to 2008 using the previous model as a baseline. In particular, we simultaneously explored 3 different factors driving bottlenose dolphin dynamics: (1) increased fishing effort and changes in nutrient concentration (baseline model); (2) competition release (baseline model); and (3) increased numbers of fish farm cages (present study).

The model incorporated available estimates of biomass and bycatch of bottlenose dolphins, as well as the biomass and catches for all the other functional groups in the ecosystem.

(1) Fishing effort and the nutrient concentration time series (Fig. 2) were used to fit predicted to observed trends over time. In particular, time series of effort for all fleets, expressed as Horse Power

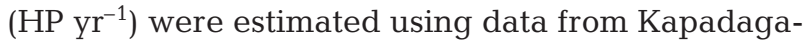
kis et al. (2001) for the period from 1996 to 2000 and 
Table 1. Functional groups and their Ecopath basic input parameters for the inner Ionian Sea Archipelago ecosystem (modified from Piroddi et al. 2010). B: biomass; P/B: production over biomass; $Q / B$ : consumption over biomass; $C$ : catch; TL: trophic level $_{i}-$ : not applicable

\begin{tabular}{|c|c|c|c|c|c|c|}
\hline Group no. & Functional group & $B$ & $P / B$ & $Q / B$ & $C$ & TL \\
\hline 1 & Short-beaked common dolphin Delphinus delphis & 0.019 & 0.09 & 24.67 & - & 4.02 \\
\hline 2 & Bottlenose dolphin Tursiops truncatus & 0.013 & 0.08 & 21.07 & - & 4.40 \\
\hline 3 & Monk seal Monachus monachus & 0.015 & 0.12 & 12.59 & & 4.23 \\
\hline 4 & $\begin{array}{l}\text { Sea birds (Calonetris diomedea, Larus cachinnans, Larus fuscus, } \\
\text { Sterna nilotica, Sterna sandvicensis, Phalacrocorax carbo) }\end{array}$ & 0.0031 & 4.6 & 105.43 & - & 3.43 \\
\hline 5 & Sea turtle Caretta caretta & 0.0069 & 0.19 & 2.54 & - & 2.81 \\
\hline 6 & Tuna (Thunnus thynnus Katsuwonus pelamis, Euthynnus alletteratus) & 0.04 & 0.2 & 3.22 & 0.0035 & 4.08 \\
\hline 7 & Swordfish Xiphias gladius & 0.06 & 0.38 & 4.4 & 0.0069 & 4.08 \\
\hline 8 & Sardines (Sardina pichardus, Sardinella aurita) & 2.1 & 1.55 & 9.84 & 0.17 & 2.89 \\
\hline 9 & Anchovy Engraulis encrasicolus & 1.2 & 1.3 & 11.66 & 0.12 & 3.11 \\
\hline 10 & $\begin{array}{l}\text { Other pelagics (Dentex dentex, Diplodus annularis, Micromesistius } \\
\text { poutassou, Mugil cephalus, Oblada melanura, Pagellus erythrinus, } \\
\text { Pagrus pagrus, Sarda sarda, Sarpa salpa, Scomber japonicus, } \\
\text { Scomber scombrus, Seriola dumerili, Spicara smaris, Spondyliosoma } \\
\text { cantharus, Sprattus sprattus, Trachurus mediterraneus, } \\
\text { Trachurus trachurus) }\end{array}$ & 1.95 & 1.95 & 7.7 & 0.37 & 3.55 \\
\hline 11 & Hake Merluccius merluccius & 0.18 & 0.82 & 3.26 & 0.022 & 3.72 \\
\hline 12 & $\begin{array}{l}\text { Other demersals (Boops boops, Lepidotrigla cavillone, Conger conger, } \\
\text { Dicentrarchus labrax, Diplodus sargus sargus, Epinephelus marginatus, } \\
\text { Helicolenus dactylopterus dactylopterus, Lophius piscatorius, } \\
\text { Mullus barbatus, Mullus surmuletus, Polyprion americanus, } \\
\text { Psetta maxima, Raya clavata, Solea solea, Sparus aurata, Scorpaenidae } \\
\text { and Serranidae) }\end{array}$ & 0.9 & 1.35 & 7.43 & 0.15 & 3.30 \\
\hline 13 & Planktivores/cages & 0.002 & 1.27 & 7.56 & - & 3.0 \\
\hline 14 & $\begin{array}{l}\text { Cephalopods (Loliginidae and Ommastrepidae families, } \\
\text { Sepia officinalis, Octopus vulgaris and other members of the family } \\
\text { Octopodidae) }\end{array}$ & 0.4 & 3.3 & 7.0 & 0.052 & 3.49 \\
\hline 15 & $\begin{array}{l}\text { Crustaceans (Hommarus gammarus, Penaeus kerathurus, } \\
\text { Carcinus aestuarii, Nephrops norvegicus and miscellaneous small } \\
\text { crustaceans) }\end{array}$ & 0.05 & 1.35 & 6.5 & 0.011 & 3.10 \\
\hline 16 & Benthic invertebrates & 28.39 & 2.5 & 22.0 & - & 2.00 \\
\hline 17 & Zooplankton & 3.7 & 31.0 & 40.0 & - & 2.10 \\
\hline 18 & Zooplankton/cages & 0.0013 & 31.0 & 40.0 & - & 2.10 \\
\hline 19 & Phytoplankton & 2.33 & 378.96 & - & - & 1.0 \\
\hline 20 & Phytoplankton/cages & 0.001 & 378.96 & - & - & 1.0 \\
\hline 21 & Discards & 0.135 & - & - & - & 1.0 \\
\hline 22 & Detritus & 69.87 & - & - & - & 1.0 \\
\hline
\end{tabular}

from Stergiou et al. (2007) for the periods from 1964 to 1995 and 2001 to 2003, while nutrient concentration was estimated by the model using a non-parametric routine. Details on time series of biomass, fishing effort, and nutrient concentration are referenced in Appendix 1.

To fit the model to observed bottlenose dolphins biomass, the 'fit to time series' procedure of Ecosim was applied by searching for those dolphin-prey vulnerability values that would minimize the sum of squared deviation (SS) of observed data from model predictions. Some of the default Ecosim parameters were also adjusted to further decrease the SS. In particular, the maximum relative feeding time and the feeding time adjustment rate for bottlenose dolphins were increased, considering that, if prey becomes scarce, these animals will spend more time looking for their food resources and will change their search feeding time as food availability varies (Christensen et al. 2008). We allowed for density-dependent predator-prey switching to take into account the well-known flexibility in the foraging behavior of bottlenose dolphins, which can adapt their diet depending on prey availability (Bearzi et al. 2008a).

(2) A 'trophic mediation function' was used to investigate whether the decline in short-beaked common dolphin biomass had 'no trophic' impact on bottlenose dolphin abundance. In Ecosim trophic 


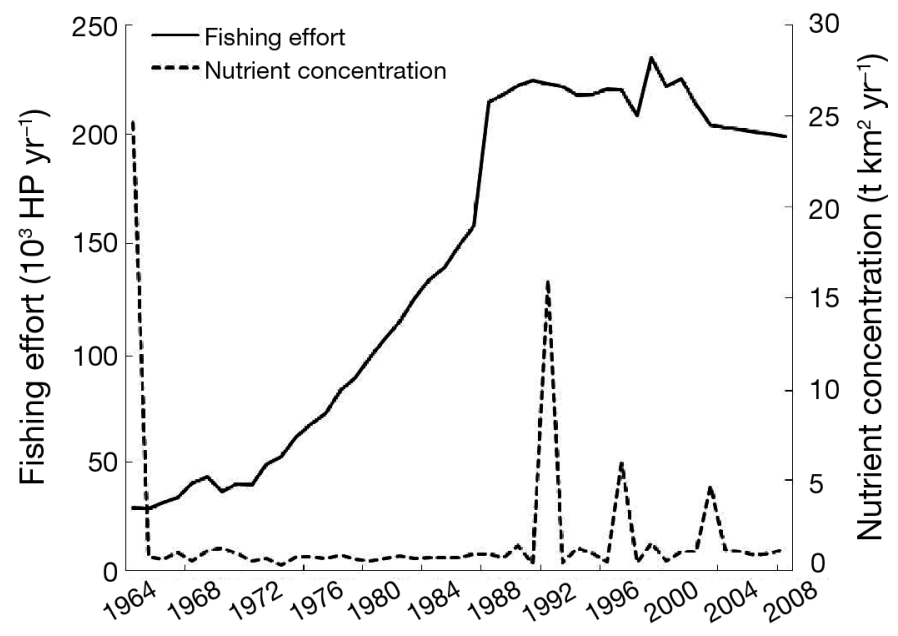

Fig. 2. Total fishing effort and nutrient concentration used as drivers in the fitting procedure. HP: horse power

interaction rates can be described as flow rates using the following formula:

$$
\text { Flow rate }=a^{*}{ }_{i j} / A_{i j} \times V_{i j} \times P_{j}
$$

where $a^{*}{ }_{i j}$ is the 'rate of effective search' parameter, $A_{i j}$ is the restricted area where predator $j$ forages on prey $i, V_{i j}$ is the vulnerable prey biomass, and $P_{j}$ is the predator abundance. This equation recognizes that predators search for prey only over restricted foraging arenas and that the vulnerable prey biomass is distributed only over such areas (Christensen et al. 2008). In Ecosim, mediation functions are used to influence the flow rate of a specific organism by altering: (a) the area over which vulnerable prey/predators are distributed, (b) the 'rate of effective search' parameter, and (c) the vulnerability exchange rate $v_{i j}$ that determines the vulnerable prey biomass $V_{i j}$. In our case, the mediation function was used to evaluate whether the observed decline in short-beaked common dolphins (Bearzi et al. 2008a) could indirectly affect (e.g. by increasing the feeding area $A_{i j}$ ) bottlenose dolphins.

(3) Lastly, we added as a forcing function the time series numbers of fish farm cages (Fig. 3) found in the study area, to further explore the trend of bottlenose dolphin biomass. In Ecosim, a 'forcing function' is used to represent physical or other environmental parameters not directly included in the model that could influence the trophic interactions of an ecosystem. In our case, the forcing function was the trend in fish cages impacting cage-associated phytoplankton. The number of cages in the study area was calculated for the years from 2002 to 2008 from highdefinition satellite images obtained through Google

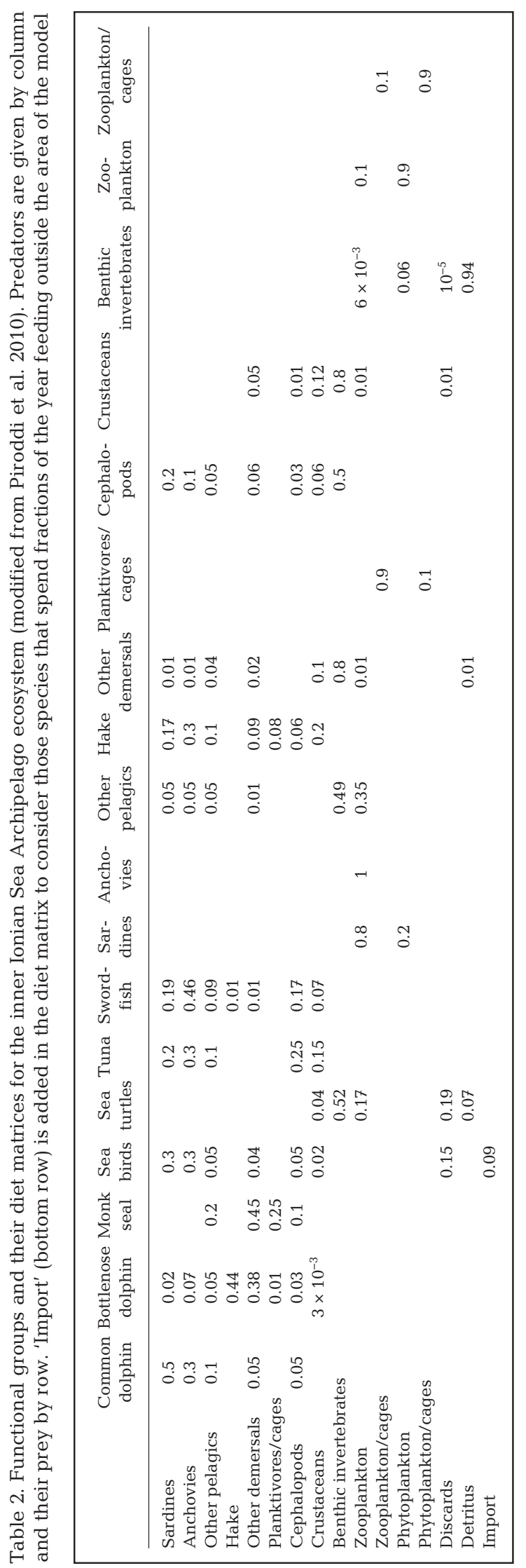




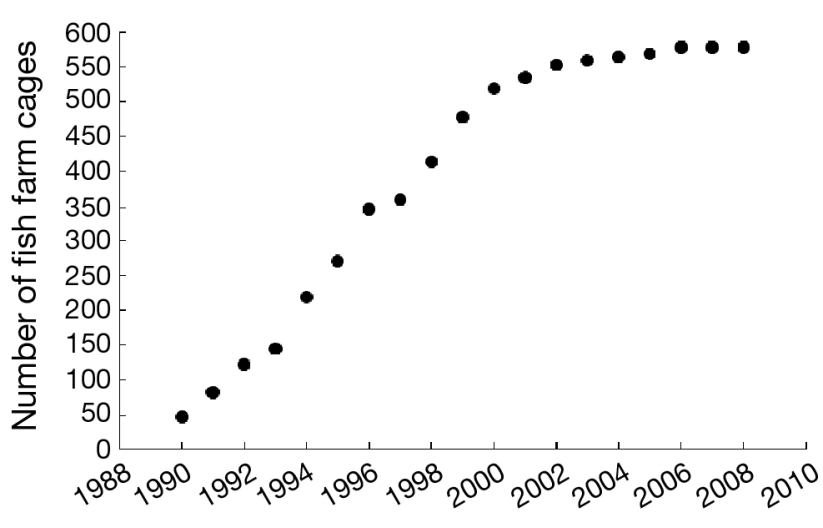

Fig. 3. Trend in number of fish farm cages estimated for the period from 1990 to 2008

Earth (Fig. 4). In particular, we followed an approach similar to that conducted by Trujillo et al. (in press) which identified and located ocean fish cages by surveying the coastline of the Mediterranean Sea and used the Google Earth 'time slider tool' to assign a temporal scale to each satellite picture available from 2002 to 2008.

Because no time series of fish cage numbers were available for the inner Ionian Sea Archipelago ecosystem for the period from 1990 to 2001, we considered the trend observed for Greece. The use of nation-wide data as a proxy for local trends is plausible given that between 1990 and 2001 the marine finfish production in the inner Ionian Sea Archipelago is known to have followed a trend similar to that of the entire region (Conides \& Kevrekidis 2005).

\section{Spatial simulations}

Ecospace is a time- and spatial-dynamic component of Ecopath and considers all the key parameters of Ecosim (Walters et al. 1999). It is based on the same set of differential equations used in Ecosim and performs a complete set of Ecosim calculations for each cell and for each time step. Each cell is linked to the rest of the cells by symmetrical movements (Christensen \& Walters 2004, Christensen et al. 2008). It is graphically represented by a grid map divided into different habitats, into which the functional groups and fishing fleets are allocated. The distribution of each group depends on habitat preference.

Ecospace was used here to investigate spatial trends in the distribution of bottlenose dolphins around fish farms. Firstly, we sketched a grid map of $30 \times 30$ cells (cell size $=1 \times 1 \mathrm{~km}$ ) to represent the study area and we assigned different habitats to each cell (Fig. 5). One habitat was defined as the fish farms, while all other habitats were classified according to bathymetry classes: 0-20 m, 21-40 m, 41-60 m, 61-80 m, 81-100 m, 101-150 m, 151-200 m, and 201-300 m. Bottlenose dolphins were allowed to distribute in all the cells, and they were assigned a dispersal rate of $190 \mathrm{~km} \mathrm{yr}^{-1}$ (Bearzi et al. 2010b). Since no dispersal rate data were available for the other organisms, we assumed a dispersal rate of $200 \mathrm{~km}$ $\mathrm{yr}^{-1}$ for the other top predators (e.g. short-beaked common dolphin, monk seal) and a value of $30 \mathrm{~km}$ $\mathrm{yr}^{-1}$ for all the other groups (Walters et al. 1999, Christensen et al. 2008). The Ecospace model was

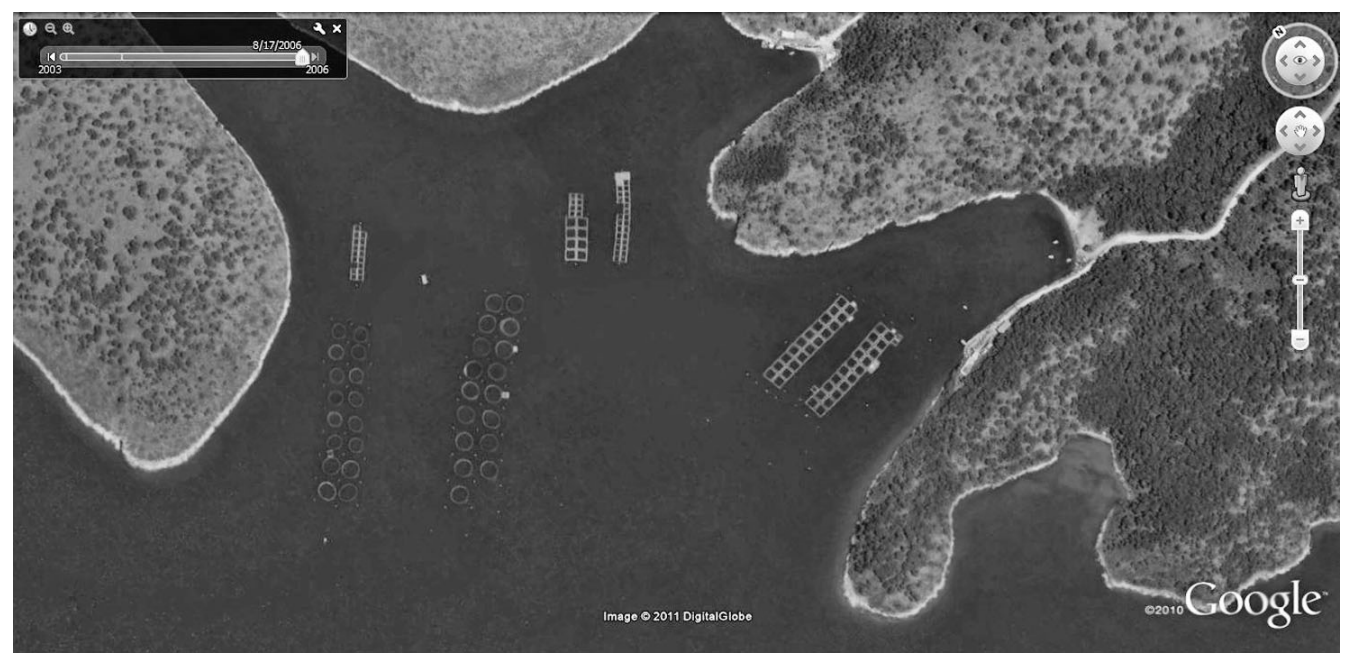

Fig. 4. Fish cages (round and rectangular) along the coast of the study area. Picture taken from Google Earth, with time slider tool (top left corner) 


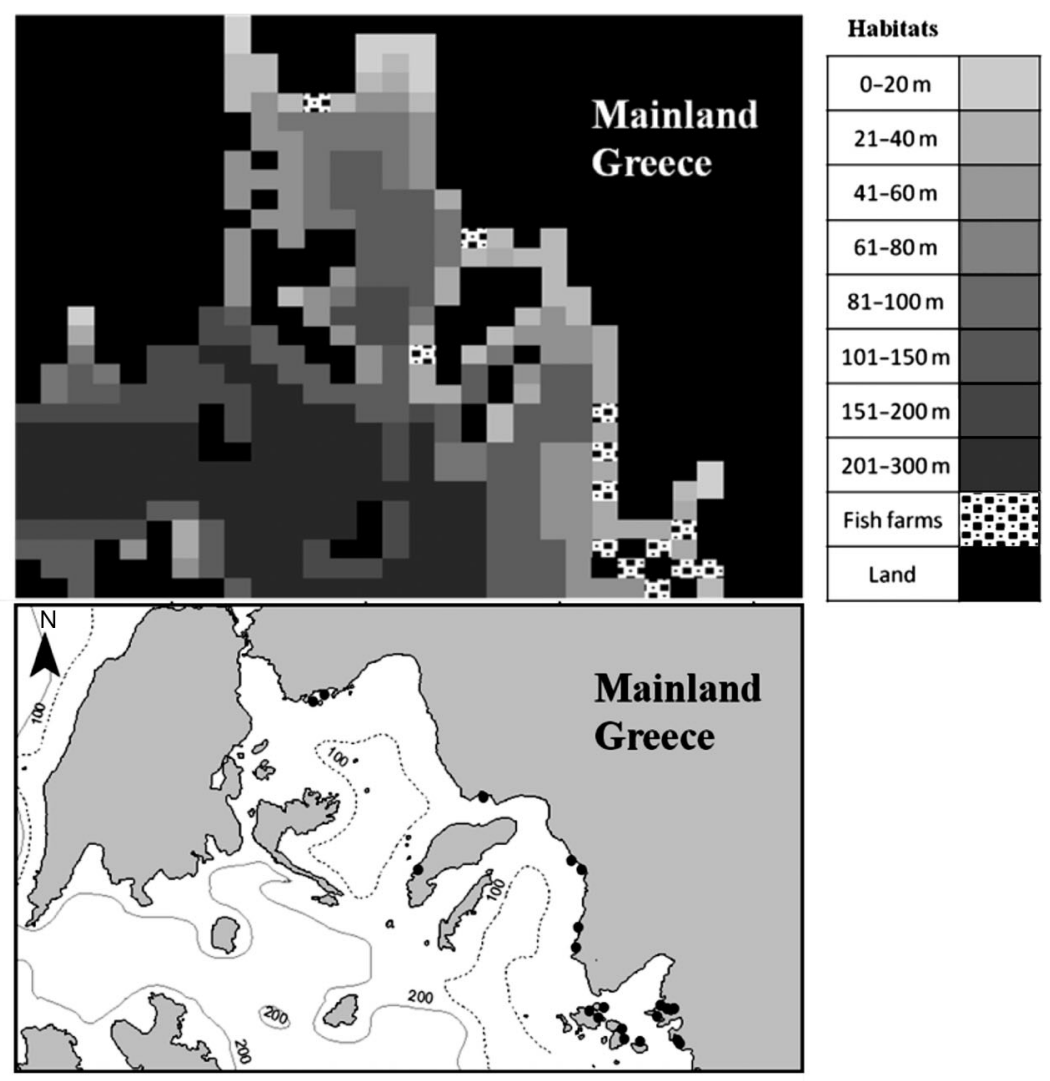

Fig. 5. The sketched Ecospace map of the inner Ionian Sea Archipelago ecosystem showing different habitats based on bathymetry classes and fish farm locations. We included a map of the study area in the lower panel to facilitate comparison

run after having fit the model to time series data, and the spatial distribution of bottlenose dolphins in the vicinity of the fish farms was obtained using a time series of the number of cages as the explanatory variable. The spatial distributions of bottlenose dolphins, their main prey, and common dolphins are displayed in Fig. S1 in the supplement at www.int-res.com/ articles/suppl/m440p255_supp.pdf.

\section{RESULTS}

\section{Ecopath input parameters and flow diagram}

The mass-balanced model for the inner Ionian Sea Archipelago for the year 1964 (Piroddi et al. 2010) was modified by adding 3 functional groups to represent those organisms in close association with fish farm cages. The model was balanced after slightly increasing the initial biomass of cage-associated planktivores and zooplankton from 0.001 and $0.002 \mathrm{t}$ $\mathrm{km}^{-2}$ to $0.0013 \mathrm{t} \mathrm{km}^{-2}$ ), respectively (Table 1). A flow diagram (Fig. 6) was created after the balancing procedure to visualize the trophic flows among trophic levels of the inner Ionian Sea Archipelago ecosystem, as well as the interactions between bottlenose dolphins and cageassociated groups.

\section{Ecosim dynamic simulation}

The baseline model reproduced the biomass trends of the main functional groups of the ecosystem relatively well (Fig. 7). The initial sum of squares $($ SSinitial $=1470)$ was greatly improved when fishing effort and nutrient concentration were included together in the fitting routine (SSfishing-nutrient $=699$ ). However, as observed by Piroddi et al. (2010), those factors were not able to explain the bottlenose dolphin population trajectory for the period from 1997 to 2008. The fit for bottlenose dolphins is displayed in Fig. 8.

When we added the 'mediation function' to the fitting procedure, no changes (SSmediation function $=699$ ) were observed in the simulated bottlenose dolphin trend. In essence, no evidence was found to support the hypothesis that short-beaked common dolphins had influenced bottlenose dolphin trend in the area (Fig. 8).

Lastly, when the time series of the number of fish cages was used as the main explanatory variable, the model was able to reconstruct the trajectory of bottlenose dolphin biomass (SSfish cages $=441$ ) through 2005 (Fig. 7). The model was unable to capture the bottlenose dolphin biomass trend in the last $3 \mathrm{yr}$ of the study (2006 to 2008) even if the simulated trajectory fell within the confidence intervals (Fig. 8).

\section{Ecospace spatial simulation}

We used Ecospace to display changes in the spatial distribution of bottlenose dolphins, the main prey sources, and common dolphins in the study area between 1964 and 2008 (maps displayed in Fig. S1). The resulting maps showed the distribution of these functional groups under 3 different fish farm development scenarios: no fish farms, early fish farm expansion, 


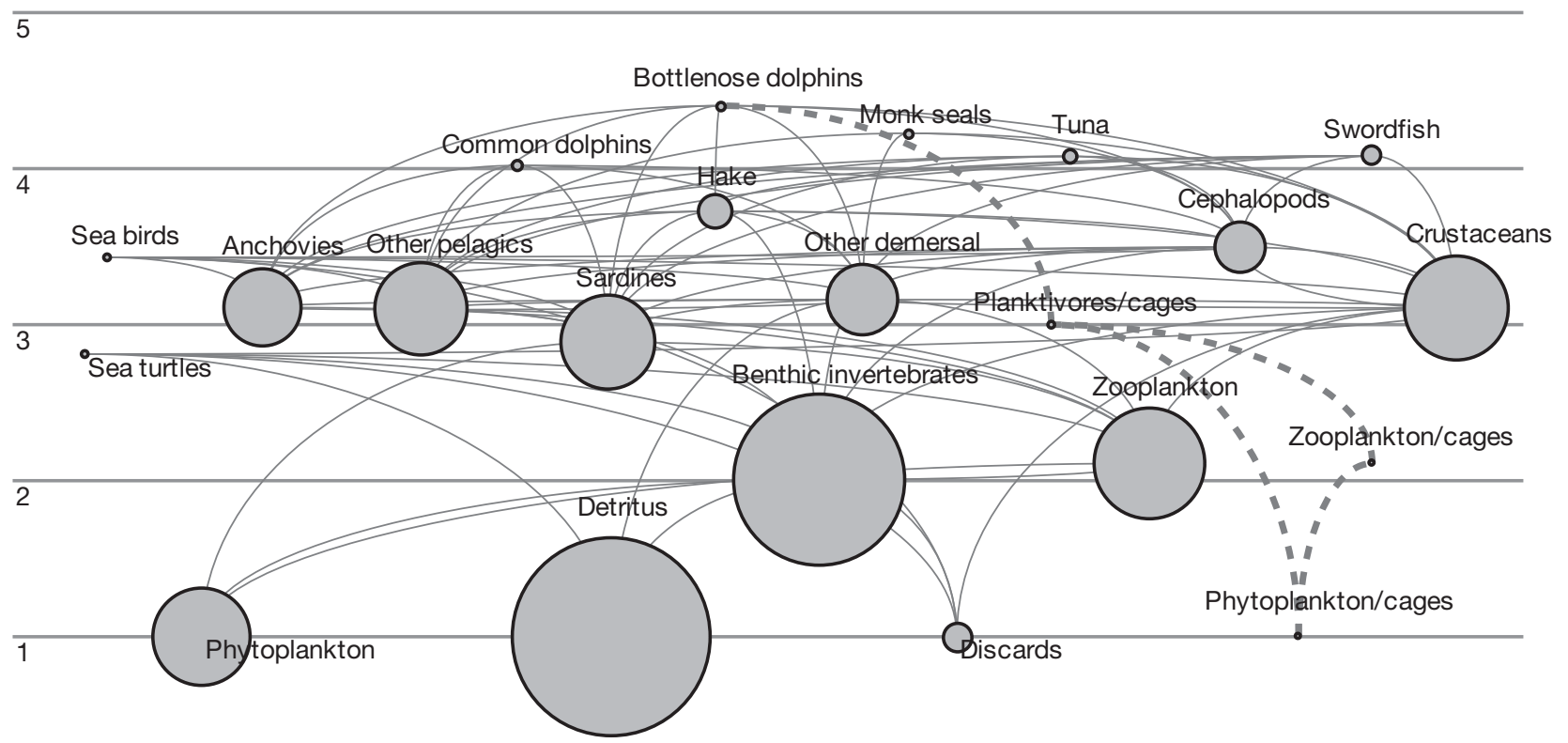

Fig. 6. Flow diagram expressing trophic flows and trophic levels of the inner Ionian Sea Archipelago ecosystem. Each functional group is represented as a circle, and its size is proportional to its biomass. The trophic interactions of bottlenose dolphins Tursiops truncatus with other prey (thin, solid lines) and with cage-associated (bold, dotted lines) planktivores, zooplankton, and phytoplankton are highlighted

and intensive fish farm expansion. The predicted spatial scenarios suggested that-in the absence of fish farms and consequently of cage-associated planktivores - bottlenose dolphins, prey, and common dolphins would distribute evenly in the study area. In contrast, expansion of fish farming operations characterized by a high abundance of cage-associated planktivores would result in a stable concentration of bottlenose dolphins distributing around marine fish culture areas and clear evidence of a decline in the other marine organisms with no changes in their spatial distribution (Fig. S1).

\section{DISCUSSION}

Mariculture production in Greece has increased largely because of the development of cage technologies in inshore waters (EEA/UNEP 2000), as well as a raising market demand for fish (Stergiou et al. 2009). Fishermen and fish farmers have often claimed that dolphins have increased largely as a result of aquaculture development, being attracted by schooling fish in the vicinity of fish farms (UNEP 1998). Also, scientists have qualitatively observed bottlenose dolphins Tursiops truncatus in the proximity of fish farm cages in several coastal areas of the northern and central Mediterranean (e.g. Díaz López \& Bernal Shirai 2007, Bearzi et al. 2009). In our study area, surveys at sea conducted between 1997 and 2008 have evidenced a relative increase in the occurrence of bottlenose dolphins searching for food and feeding around coastal fish farms (Bearzi et al. 2008a, 2009). Such an increase in dolphin concentration around fish farms has been suggested to be related to the high density of wild fish species in the vicinity of the fish cages (e.g. Díaz López \& Bernal Shirai 2007, Bearzi et al. 2009). Sea-cage fish farms act as 'super-FADs' (FAD: fish aggregation device; Dempster et al. 2002), attracting a large variety of wild fish that feed on large food pellets lost through the cages, and/or on particulate organic matter (POM) from broken pellets and feces (Dempster et al. 2002, Machias et al. 2004, 2005, Giannoulaki et al. 2005). While this could imply only a spatial redistribution of wild fish surrounding seacage fish farms with no evidence of increase in their total biomass, Machias et al. (2006) have demonstrated that, in both Ionian and Aegean Seas, such an increase in fish farm facilities leads to an increase in biomass of commercially important fish stocks. Such a mechanism, particularly in oligotrophic ecosystems, is related not only to the direct consumption of feed pellets around the fish cages, but also, and principally, to the increase in primary production through released nutrients and a rapid transfer of these nutrients up the food web, with a strong influence on the coupling between pelagic and benthic compartments (Belias et al. 2003, Machias et al. 2006, Pitta et al. 2009). 

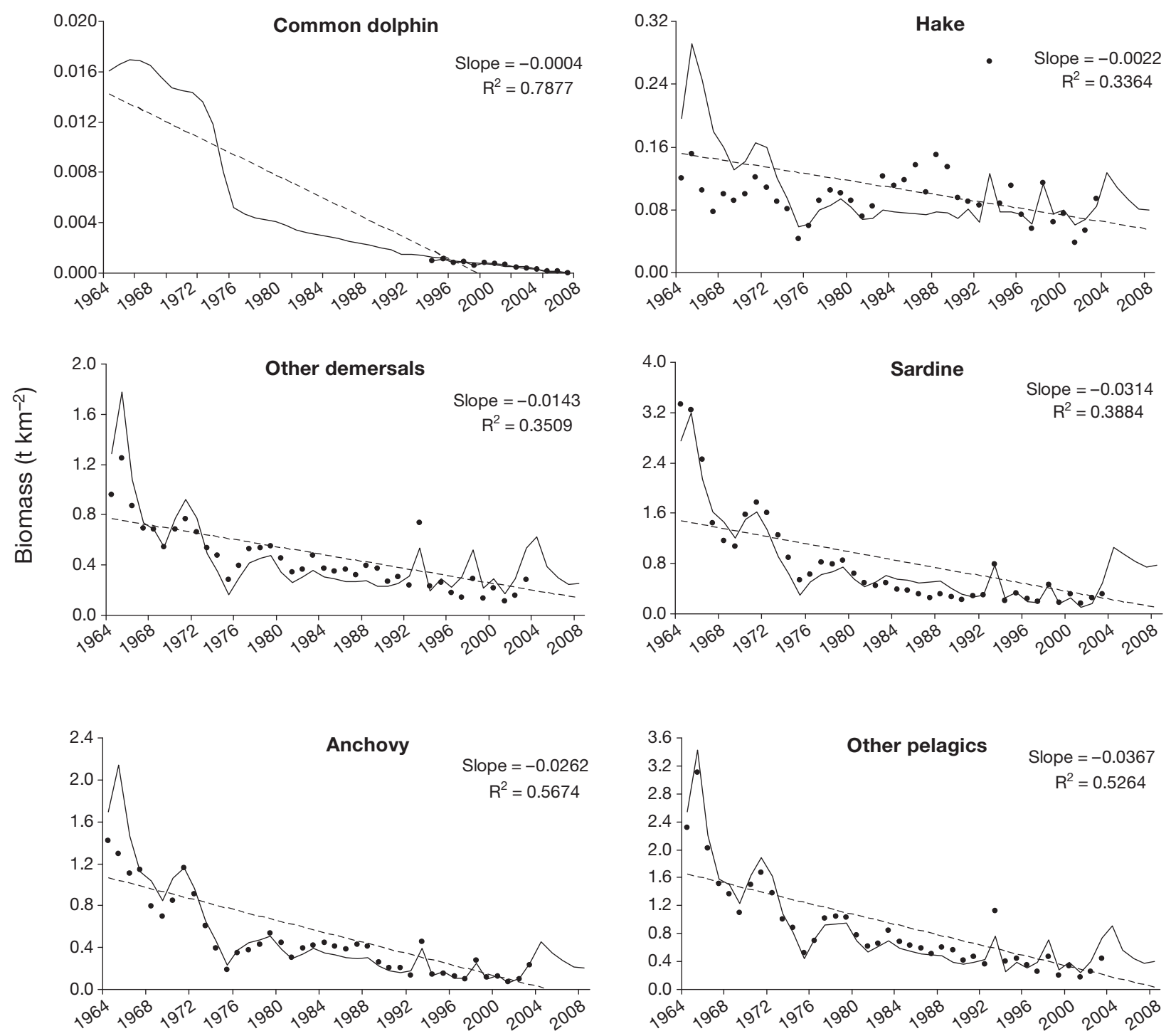

Fig. 7. Predicted (solid lines) versus observed (dots) biomass ( $\mathrm{km}^{-2}$ ) for common dolphin Delphins delphis and the main bottlenose dolphin Tursiops truncatus prey, using time series of fishing effort and changes in nutrient concentration as drivers. Parameters of linear regression (dashed lines) are indicated

Bottlenose dolphins are known to be opportunistic allowing them to adapt to changes in prey availability (Shane et al. 1986, Bearzi et al. 2008b) and to take advantage of human activities by either following fishing boats to feed on discarded fish (Fertl \& Leatherwood 1997, Bearzi et al. 1999), by catching/ stealing fish during fishing operations (Diaz López 2006, Lauriano \& Bruno 2007, Gonzalvo et al. 2008), or by feeding near fish farm facilities (Díaz López \& Bernal Shirai 2007, Bearzi et al. 2009). This feeding strategy has most likely been adopted by bottlenose dolphins to increase their feeding rate, while decreasing the energy expenditure associated with foraging (Fertl \& Leatherwood 1997), in order to com- pensate for the lack of fish prey in the surrounding waters. Recent studies have demonstrated how overfishing has caused detrimental effects on fish stocks in the study area (Bearzi et al. 2008a, Gonzalvo et al. 2010, Piroddi et al. 2010), including important prey of bottlenose dolphins (Bearzi et al. 2010a). It is possible that a decrease in the availability of prey prompted the behaviorally flexible and opportunistic bottlenose dolphin to focus (at least in part) on fish resources located around fish farm cages. While such a link has often been proposed, to our knowledge it has never been documented-making the present study the first attempt to investigate the trophic mechanisms behind this interaction. 


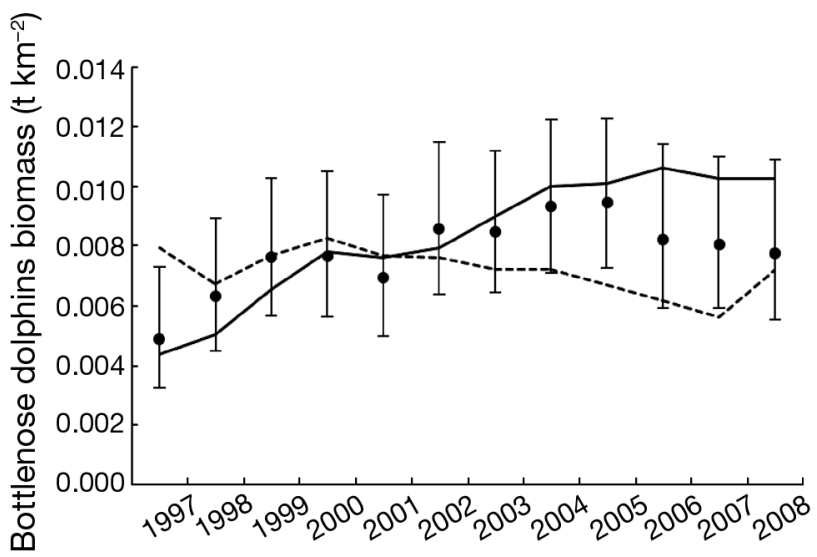

Fig. 8. Tursiops truncatus. Predicted (lines) versus observed (dots, mean \pm SD) biomass of bottlenose dolphins, using (1) time series of fishing effort and changes in nutrient concentration as drivers, and the mediation function approach (dashed line), and (2) the number of fish farm cages as the driver (solid line)

Ecosystem modeling approaches have been used increasingly to understand the trophic role of marine mammals and their dynamic interactions with other marine organisms, as well as human activities (mainly fisheries; Guénette et al. 2006, Gerber et al. 2009, Morissette et al. 2010). Using such an approach, we showed how the rapid development of marine fish culturing along the coasts of the study area has directly influenced the bottlenose dolphin distribution. Our results suggest that, while increased fishing effort and changes in ocean productivity could be used to explain the decline of major fish stocks and top predators in the area, the expansion of aquaculture facilities and the consequent increase in productivity in the water column was the only key factor influencing the dynamics of bottlenose dolphins. Furthermore, no evidence was found to indicate that the decline in short-beaked common dolphins indirectly affected the bottlenose dolphins through a 'competition release' mechanism (e.g. by increasing the feeding area). Our model was unable to replicate the bottlenose dolphin trend in the last 3 yr of the study (2006 to 2008). Several interpretations could possibly explain such trajectory (e.g. sea-cage aquaculture is just a limiting source of food and has reached its maximum contribution in the bottlenose dolphins diet, or that fishing in the area has depleted prey to a level that bottlenose dolphins cannot compensate by going to the cages for additional food); however, we believe that $3 \mathrm{yr}$ are not sufficient to provide an explanation for this trend and more studies are needed to test these hypotheses.

Despite the potentially positive effects of open cage aquaculture on bottlenose dolphin populations re- sulting from increased prey availability and the ease of catching prey, several factors could also be of concern. For instance, the supply of hormones and antibiotics to farmed fish to improve fish productivity could affect dolphin reproduction or reduce their resistance to pathogens (Parsons et al. 2000, Würsig \& Gailey 2002). Another potential impact could result from the interaction between this cetacean and fish farmers (Díaz López \& Bernal Shirai 2007). So far, in the Mediterranean Sea, only one study has attempted to estimate, using an ecosystem modeling approach, the impact of dolphins on aquaculture infrastructures (i.e. by stressing farmed fish), and that study found no substantial disturbance (Díaz López et al. 2008).

The present study suggests that fish farms may play an important trophic role in oligotrophic and overfished areas such as the inner Ionian Sea Archipelago. However, the modeling approach used here has still some weaknesses. The spatial distribution of bottlenose dolphins around the cages may be influenced by more factors than those included here. Fish farm location (e.g. coastal versus open ocean) and ecosystem type (e.g. oligotrophic versus eutrophic) are likely crucial factors. Preference for certain fish farms may be influenced by their spatial location as well as by the fish species that aggregate around the cages. Future studies should investigate to what extent dolphin presence around fish farms is driven by the nature of the ecosystem and by the type of fishes that surround the cages. Also, this ecosystem was modeled looking at the increase of phytoplankton, zooplankton, and fish due to the increased number of cages in the area. Biogeochemical processes induced by open cage aquaculture (e.g. nutrients, food pellets, dissolved oxygen) are important factors affecting food web dynamics, and they should be explored and integrated in future model construction.

Acknowledgements. V.C. acknowledges support from the National Science and Engineering Research Council of Canada and the Sea Around Us Project, a scientific cooperation between the University of British Columbia and the Pew Environment Group. G.B. is grateful to OceanCare, WDCS The Whale and Dolphin Conservation Society, and UNEP's Regional Activity Centre for Specially Protected Areas (RAC-SPA). Our thanks go to all those who contributed to field data collection and data analysis. Moreover, we thank Jennifer Jacquet and Vasiliki Karpouzi for useful comments on the manuscript.

\section{LITERATURE CITED}

Androukaki E, Adamantopoulou S, Dendrinos P, Tounta E, Kotomatas S (1999) Causes of mortality in the Mediterranean monk seal (Monachus monachus) in Greece. Contrib Zool Ecol Eastern Mediterr Reg 1:405-411 
Bearzi G, Politi E, Di Sciara G (1999) Diurnal behavior of free-ranging bottlenose dolphins in the Kvarneric (northern Adriatic Sea). Mar Mamm Sci 15:1065-1097

Bearzi G, Agazzi S, Gonzalvo J, Costa M and others (2008a) Overfishing and the disappearance of short-beaked common dolphins from western Greece. Endang Species Res 5:1-12

Bearzi G, Azzellino A, Politi E, Costa M, Bastianini M (2008b) Influence of seasonal forcing on habitat use by bottlenose dolphins Tursiops truncatus in the northern Adriatic Sea. Ocean Sci J 43:175-182

> Bearzi G, Fortuna C, Reeves R (2009) Ecology and conservation of common bottlenose dolphins Tursiops truncatus in the Mediterranean Sea. Mammal Rev 39:92-123

Bearzi G, Agazzi S, Gonzalvo J, Bonizzoni S, Costa M, Petroselli A (2010a) Biomass removal by dolphins and fisheries in a Mediterranean Sea coastal area: Do dolphins have an ecological impact on fisheries? Aquat Conserv 20:549-559

> Bearzi G, Bonizzoni S, Gonzalvo J (2010b) Mid-distance movements of common bottlenose dolphins in the coastal waters of Greece. J Ethol 29:369-374

> Belias CV, Bikas V, Dassenakis M, Scoullos M (2003) Environmental impacts of coastal aquaculture in eastern Mediterranean bays the case of Astakos Gulf, Greece. Environ Sci Pollut Res 10:287-295

> Casotti R, Landolfi A, Brunet C, D'Ortenzio F, Mangoni O (2003) Composition and dynamics of the phytoplankton of the Ionian Sea (eastern Mediterranean). J Geophys Res 108:8116 doi: 10.1029/2002JC001541

> Christensen V, Walters C (2004) Ecopath with Ecosim: methods, capabilities and limitations. Ecol Model 172: 109-139

Christensen V, Walters C, Pauly D, Forrest R (2008) Ecopath with Ecosim 6: a user's guide. Fisheries Centre, University of British Columbia, Vancouver

Coll M, Palomera I, Tudela S, Dowd M (2008) Food-web dynamics in the South Catalan Sea ecosystem (NW Mediterranean) for 1978-2003. Ecol Model 217:95-116

Coll M, Santojanni A, Palomera I, Arneri E (2009) Food-web changes in the Adriatic Sea over the last three decades. Mar Ecol Prog Ser 381:17-37

- Coll M, Piroddi C, Steenbeek J, Kaschner K and others (2010) The biodiversity of the Mediterranean Sea: estimates, patterns, and threats. PLoS ONE 5:e11842

Coll M, Piroddi C, Albouy C, Ben Rais Lasram F and others (2011) The Mediterranean Sea under siege: spatial overlap between marine biodiversity, cumulative threats and marine reserves. Glob Ecol Biogeogr doi: 10.1111/j. 1466-8238.2011.00697.x

Conides A, Kevrekidis K (2005) Marine aquaculture sector of Hellas 1985-2002. In: Papathanassiou E, Zenetos A (eds) State of the Hellenic marine environment. HCMR, Athens, p 285-294

Costello MJ, Coll M, Danovaro R, Halpin P, Ojaveer H, Miloslavich P (2010) A census of marine biodiversity knowledge, resources, and future challenges. PLoS ONE 5:e12110

> Crowder L, Hazen E, Avissar N, Bjorkland R, Latanich C, Ogburn M (2008) The impacts of fisheries on marine ecosystems and the transition to ecosystem-based management. Annu Rev Ecol Evol Syst 39:259-278

Dempster T, Sanchez-Jerez P, Bayle-Sempere J, GiménezCasalduero F, Valle C (2002) Attraction of wild fish to sea-cage fish farms in the south-western Mediterranean Sea: spatial and short-term temporal variability. Mar Ecol Prog Ser 242:237-252
Díaz López B (2006) Interactions between Mediterranean bottlenose dolphins (Tursiops truncatus) and gillnets off Sardinia, Italy. ICES J Mar Sci 63:946-951

Díaz López B, Bernal Shirai J (2007) Bottlenose dolphin (Tursiops truncatus) presence and incidental capture in a marine fish farm on the north-eastern coast of Sardinia (Italy). J Mar Biol Assoc UK 87:113-117

Díaz López B, Polo F, Marini L (2005) The impact of a fish farm on a bottlenose dolphin population in the Mediterranean Sea. Thalassas 21:65

> Díaz López B, Bunke M, Bernal Shirai JA (2008) Marine aquaculture off Sardinia Island (Italy): ecosystem effects evaluated through a trophic mass-balance model. Ecol Modell 212:292-303

EEA/UNEP (European Environment Agency/United Nations Environment Program) (2000) State and pressures of the marine and coastal Mediterranean environment. Environmental Issues Series 5, EEA/UNEP, Copenhagen

Fertl D, Leatherwood S (1997) Cetacean interactions with trawls: a preliminary review. J Northwest Atl Fish Sci 22: 219-248

Gerber LR, Morissette L, Kaschner K, Pauly D (2009) Should whales be culled to increase fishery yield? Science 323: 880-881

Giannoulaki M, Machias A, Somarakis S, Karakassis I (2005) Wild fish spatial structure in response to presence of fish farms. J Mar Biol Assoc UK 85:1271-1277

Gonzalvo J, Valls M, Cardona L, Aguilar A (2008) Factors determining the interaction between common bottlenose dolphins and bottom trawlers off the Balearic Archipelago (western Mediterranean Sea). J Exp Mar Biol Ecol $367: 47-52$

Gonzalvo J, Moutopoulos D, Bearzi G, Stergiou K (2010) Fisheries mismanagement in a Natura 2000 area in western Greece. Fish Manag Ecol 18:25-38

Guénette S, Heymans S, Christensen V, Trites A (2006) Ecosystem models show combined effects of fishing, predation, competition, and ocean productivity on Steller sea lions (Eumetopias jubatus) in Alaska. Can J Fish Aquat Sci 63:2495-2517

> Heithaus MR, Frid A, Wirsing A, Worm B (2008) Predicting ecological consequences of marine top predator declines. Trends Ecol Evol 23:202-210

Kapadagakis A, Machias A, Stergiou K, Somarakis S and others (2001) Patterns and propensities in Greek fishing effort and catches. IMBC and Aristotle University, Thessaloniki

> Karakassis I, Pitta P, Krom M (2005) Contribution of fish farming to the nutrient loading of the Mediterranean. Sci Mar 69:313-321

Kastelein R, Macdonald G, Wiepkema P (2000) A note on food consumption and growth of common dolphins (Delphinus delphis). J Cetacean Res Manag 2:69-74

Katranidis S, Nitsi E, Vakrou A (2003) Social acceptability of aquaculture development in coastal areas: the case of two Greek Islands. Coast Manag 31:37-53

Lauriano G, Bruno S (2007) A note on the acoustic assessment of bottlenose dolphin behaviour around fishing gears in the Asinara Island National Park, Italy. J Cetacean Res Manag 9:137-141

Mace P (2001) A new role for MSY in single-species and ecosystem approaches to fisheries stock assessment and management. Fish Fish 2:2-32

- Machias A, Karakassis I, Labropoulou M, Somarakis S, Papadopoulou K, Papaconstantinou C (2004) Changes in wild fish assemblages after the establishment of a fish 
farming zone in an oligotrophic marine ecosystem. Estuar Coast Shelf Sci 60:771-779

Machias A, Karakassis I, Giannoulaki M, Papadopoulou K, Smith C, Somarakis S (2005) Response of demersal fish communities to the presence of fish farms. Mar Ecol Prog Ser 288:241-250

Machias A, Giannoulaki M, Somarakis S, Maravelias C and others (2006) Fish farming effects on local fisheries landings in oligotrophic seas. Aquaculture 261:809-816

Morissette L, Kaschner K, Gerber L (2010) Ecosystem models clarify the trophic role of whales off Northwest Africa. Mar Ecol Prog Ser 404:289-302

Parsons E, Shrimpton J, Evans P (2000) Cetacean conservation in Northwest Scotland: perceived threats to cetaceans. In: Evans P, Raga J, Cruz J (eds) Proceedings of the 13th annual conference of the European Cetacean Society. ECS, Valencia, p 128-133

Pauly D, Christensen V (2002) Ecosystem models. In: Hart P, Reynolds J (eds) Handbook of fish and fisheries, Vol 2. Blackwell Science, Oxford, p 211-227

Pauly D, Christensen V, Guénette S, Pitcher T and others (2002) Towards sustainability in world fisheries. Nature 418:689-695

Piroddi C, Bearzi G, Christensen V (2010) Effects of local fisheries and ocean productivity on the northeastern Ionian Sea ecosystem. Ecol Model 221:1526-1544

Pitta P, Karakassis I, Tsapakis M, Zivanovic S (1998a) Natural vs. mariculture induced variability in nutrients and plankton in the eastern Mediterranean. Hydrobiologia 391:179-192

Pitta P, Tsapakis M, Zivanovic S, Karakassis I (1998b) Seasonal variability of water column biogeochemistry in three coastal areas in the Ionian and Aegean Seas. Rapp Comm Int Mer Mediterr 35:284-285

Pitta P, Tsapakis M, Apostolaki ET, Tsagaraki T, Holmer M, Karakassis I (2009) Ghost nutrients' from fish farms are transferred up the food web by phytoplankton grazers. Mar Ecol Prog Ser 374:1-6

Plagányi E, Butterworth D (2004) A critical look at the potential of Ecopath with Ecosim to assist in practical fisheries management. Afr J Mar Sci 26:261-287

Sarà G, Scilipoti D, Mazzola A, Modica A (2004) Effects of fish farming waste to sedimentary and particulate organic matter in a southern Mediterranean area (Gulf of Castellammare, Sicily): a multiple stable isotope study $\left({ }^{13} \mathrm{C}\right.$ and $\left.{ }^{15} \mathrm{~N}\right)$. Aquaculture 234:199-213

Shane SH, Wells RS, Würsig B (1986) Ecology, behavior and social organization of the bottlenose dolphin: a review.
Mar Mamm Sci 2:34-63

Smith A, Fulton E, Hobday A, Smith D, Shoulder P (2007) Scientific tools to support the practical implementation of ecosystem-based fisheries management. ICES J Mar Sci 64:633-639

Stergiou KI, Koulouris M (2000) Fishing down the marine food webs in the Hellenic seas. In: Briand F (ed) Fishing down the Mediterranean food webs? CIESM Workshop Monographs 12, p 73-78

Stergiou KI, Moutopoulos D, Tsikliras A, Papaconstantinou C (2007) Hellenic marine fisheries: a general perspective from the National Statistical Service data. In: Papaconstantinou C, Zenetos A, Vassilopoulou V, Tserpes G (eds) State of Hellenic fisheries. Hellenic Centre for Marine Research, Anavyssos Attiki, p 132-140

> Stergiou KI, Tsikliras A, Pauly D (2009) Farming up Mediterranean food webs. Conserv Biol 23:230-232

Trujillo P, Piroddi C, Jacquet J (in press) Fish farms at sea: the ground truth from Google Earth. PLoSOne

Tsikliras A, Moutopoulos D, Stergiou K (2007) Reconstruction of Greek marine fisheries landings: national versus FAO statistics. In: Zeller D, Pauly D (eds) Reconstruction of marine fisheries catches for key countries and regions (1950-2005). Fisheries Centre Research Report, Vancouver, p 127-137

UNEP (United Nations Environment Program) (1998) Report of the meeting of experts on the implementation of the action plans for marine mammals (monk seal and cetaceans) adopted within MAP. UNEP(OCA)/MED WG146/5, www.unepmap.org

UNEP/MAP/MED POL (United Nations Environment Program/Mediterranean Action Plan/Mediterranean Pollution) (2004) Mariculture in the Mediterranean. Technical Reports Series 140, MAP, Athens

Walters C, Christensen V, Pauly D (1997) Structuring dynamic models of exploited ecosystems from trophic mass-balance assessments. Rev Fish Biol Fish 7:139-172

> Walters C, Pauly D, Christensen V (1999) Ecospace: prediction of mesoscale spatial patterns in trophic relationships of exploited ecosystems, with emphasis on the impacts of marine protected areas. Ecosystems 2:539-554

Watson-Capps J, Mann J (2005) The effects of aquaculture on bottlenose dolphin (Tursiops sp.) ranging in Shark Bay, Western Australia. Biol Conserv 124:519-526

Würsig B, Gailey G (2002) Marine mammals and aquaculture: conflicts and potential resolutions. In: Stickney RR, McVey JP (eds) Responsible marine aquaculture. CAB International, Wallingford, p 45-59

Appendix 1. Time series of biomass, fishing effort, and nutrient concentration used in the fitting procedure of Ecosim

\begin{tabular}{lcl}
\hline Time series & Years & \multicolumn{1}{c}{ Source } \\
\hline Short-beaked common dolphin biomass & $1995-2007$ & Kastelein et al. (2000), Bearzi et al. (2008a) \\
Bottlenose dolphin biomass & $1997-2008$ & Tethys Research Institute (unpubl. data) \\
Hake biomass & $1964-2003$ & Tsikliras et al. (2007), Piroddi et al. (2010) \\
Sardine biomass & $1964-2003$ & Tsikliras et al. (2007), Piroddi et al. (2010) \\
Anchovy biomass & $1964-2003$ & Tsikliras et al. (2007), Piroddi et al. (2010) \\
Other demersals' biomass & $1964-2003$ & Tsikliras et al. (2007), Piroddi et al. (2010) \\
Other pelagics' biomass & $1964-2003$ & Tsikliras et al. (2007), Piroddi et al. (2010) \\
Fishing effort & $1964-2008$ & Kapadagakis et al. (2001), Stergiou et al. \\
& & (2007), Piroddi et al. (2010) \\
Nutrient concentration & $1964-2008$ & Piroddi et al. (2010)
\end{tabular}

